\title{
Determinants of Migration and its Impact on Socio- Economic Welfare of Households in Tigrai, Ethiopia
}

\author{
Meron Zenaselase \\ Department of Economics, Adigrat University
}

\begin{abstract}
Ethiopia is one of the countries in Africa with a relatively high level of internal migration and population redistribution. Migration of rural Tigrian youth to different towns within the region was a common trend in earlier times. Population growth accompanied by poverty, lack of education and employment opportunities are the major driving forces of rural persons to migrate from the villages to towns in search of better opportunities. The incidence of poverty level in Tigray is about 32.6\% (2010/11). Since there was no clear statistical data that indicates the number of youth migrated since the means applied are variety and illegal. Hence, this study examined the macro and micro level evidences regarding magnitude and determinants of migration, and its implications on structural and socio-economic conditions of rural and urban households. The study employed 270 households with equal share of these households having migrant members and the non-migrant households. Based upon the incidence of migration in the zone, 50 percent, of the sample was allocated to three rural areas of Eastern zone and 50 percent was allocated to urban areas who were migrated near the rural areas. Three woredas from the zone, known for their high level of migration, was selected purposefully and sample households were selected randomly from the frame list of the migrant and non migrant households. The descriptive analysis of research work founds high costs of living and low level of education of migrants had created disincentives and constraints of migration to the towns. In addition, the research suggests that the reason for migrating changes across different area of destination, with Adigrat attracting the greatest flows of work- and educational-related migration which can be regarded as pull factors while in the remaining two towns Wukro and Atsibi Wenberta the greatest flows can be regarded as push factors because of less agricultural productivity, no or less access to land and poverty. The study also finds migrants afford to send money and other resources to home. Though the remittance rate is low, the reasons might limit the benefits accruing to family members left behind. Last but not the least, the research recommends rural urban migration should be incorporated in the GTP II plan to enhance rural development and reduce poverty. The policy papers should be designed in the ways of maximizing the benefits of migration and minimizing the negative outcomes. Likewise, rural development policies should pave opportunities to enable migrants to involve in farm and non-farm investments. Non-farm enterprises serve as a means of rural livelihood diversification and reduce the pressure on land. Side by side, Vocational training should be given for rural migrants to equip them with the necessary skills and make them competitive in the non-farm labor market.
\end{abstract}

Keywords: Rural urban Migration, causes and consequences, OLS method

\section{Introduction}

\section{Background and Justification}

Ethiopia is a poor country that has struggled with drought, famines, overpopulation, poverty, and political instability.

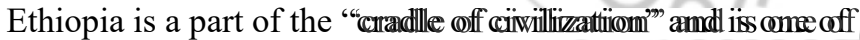
the few countries to never be colonized. This has not, however, prevented the country from suffering ethnic conflict and political instability. Today Ethiopia is officially a democratic country, although the volatile politics and ethnic conflict have contributed to poor governance which, combined with overpopulation and drought, have led to devastating impacts for Ethiopians during the country's famines, resettlement programmes, and political repression (Bariagaber, 1999).

Ethiopia is one of the poorest countries in the world and in 2005 had an emigration rate of 0.6 percent, which is low in comparison to Africa as a whole. Political instability in the 1970 s and the large refugee flows of the 1980s led to the development of the Ethiopian Diaspora, which today is actively engaged in political and development processes in Ethiopia. The Ethiopian Diaspora is one of the largest of all African countries and is concentrated primarily in the United States and United Kingdom. Remittances to Ethiopia from the Diaspora provide an integral source of income for families to sustain themselves through external shocks and meet their basic needs (Bariagaber, 1999).

Internal migration flows in Ethiopia are currently larger than external flows, but the exact number of people who migrate internally is not known. Internal migration occurs in the form of rural-urban migration, rural-rural migration, and resettlement policies, which are all substantial in Ethiopia. Ethiopia is one of the countries in Africa with a relatively high level of internal migration and population redistribution. Researchers have shown how the character, direction, and volume of migration in Ethiopia in the last two to three decades have been shaped by political instability, decline in the agricultural sector, and government resettlement policies of the $1980 \mathrm{~s}$, whose official objective was to prevent famine and attain food security (Gebre, 2001; Ezra, 2001). Under these circumstances, migration became not only an individual or family response to an adverse socioeconomic, physical and political environment, but also an official government policy.

While these forces have combined to promote the redistribution of the population over the last several years (Berhanu and White, 2000), empirical assessments of the consequences of these movements on the living conditions of migrants and their households in Tigray national regional state remains limited. 


\section{International Journal of Science and Research (IJSR) \\ ISSN (Online): 2319-7064}

Index Copernicus Value (2015): 78.96 | Impact Factor (2015): 6.391

Until the early 1990s, Ethiopia was one of the largest producers of migrants in Africa (Bariagaber, 1999). On the other hand, the number of refugees from Ethiopia increased from 55,000 in 1972 to over a million in 1992 in international migration. Even though Ethiopia has experienced migratory flows throughout its history, the movement of Ethiopian civilians became substantially greater in the late 1960s and 1970s (Berhanu, Kassahun, Seid \& Zekarias, 2004). Especially after the 1974 revolution, large migration flows started to arise. Most of the migrants from Ethiopia were refugees, escaping political conflict, famine, and persecution (Bariagaber, 1997), often by their own government (De Waal, 1991). The refugees from Ethiopia are depicted as "[...] a mass of fleeing individuals primarily interested in safely and quickly reaching neighboring countries" (Bariagaber, 1997). Motives to flee have changed over time, however. Migrants initially fled for political reasons and to escape conflict. In later years the motives of Ethiopian migrants to flee their country shifted to more economic motives (ibid).

Migration of rural Tigrian youth to different towns within the region was a common trend in earlier times. Population growth accompanied by poverty, lack of education and employment opportunities are the major driving forces of rural persons to migrate from the villages to towns in search of better opportunities. The incidence of poverty level in Tigray is about $32.6 \%(2010 / 11)$. Moreover, the Unemployment rate encompasses $19 \%$ [11.2\% male and $26.2 \%$ female (2009). Since unemployment in the region is a major problem, the towns were no better places to provide such opportunities. Hence, illegal migration and/ or human trafficking may be viewed as a symptom of absolute and/ or relative poverty and unemployment particularly among young people. Therefore, it is a response to the demand formainly - youth for various forms of exploitation. Thus, combating human trafficking also involves addressing the causes of poverty. Moreover, in order to more effectively combat the practice of human trafficking, it is very important to understand the characteristics of trafficked people. Thus, it is important to gain a better understanding of the economic and political conditions that make trafficking more prominent in some regions, zones and/or woredas rather than others. Hence, one of the objectives of this research project is to fill this research gap by identifying the causes of illegal migration and/ or human trafficking.

Researchers are also increasingly pointing to the vulnerability of migrants to adverse living conditions in their urban destinations. The rapid urbanization in the region, the unprecedented growth in the size of the population of young people, and the declining economic performance of most African countries have been linked to a new face of poverty, with a significant proportion of the population living below the poverty line in over-crowded slums and sprawling shanty towns around major cities (UN-HABITAT, 2003). This pattern of urban living is characterized by high levels of unemployment and underemployment, poverty, crime, risky reproductive behavior, generally debilitating environmental conditions, and poor health outcomes (Brockerhoff and Brenan, 1998).
The history of Ethiopia in the last three decades as reviewed above made outmigration for many not just the rational choice but the only choice. Dejene (1990) suggests that migration from the villages of Wollo in northeast Ethiopia to the resettlement villages was a last resort and for migrants the choice was often between death and migration. Consequently, those who move are often the economically marginally-embedded in the place of origin with no locational incentive to stay. Gurmu et al (2000) identifies particularly the increased volume of movement of vulnerable women and young people with little education and few job skills, with a high proportion being domestic or service workers. In the same light, Ezra (2001) demonstrates that rural out-migration in northern Ethiopia has been a response to push factors related to ecological degradation and poverty in rural areas, rather than a response to pull factors from urban areas. Under these circumstances, the potential outcomes of such moves are hardly optimistic.

In a nutshell, some of the causes of migration and/ or human trafficking are structural in character and require long-term solutions. At the same time, the seriousness of the problem and its changing nature require immediate and rapid response, timely measures, and the flexibility to rethink and change direction where necessary. However, there is no clear statistical data that indicates the number of youth trafficked since the means applied are variety and illegal. Hence, this study will examine the macro and micro level evidences regarding magnitude and determinants of migration, and its implications on structural and socioeconomic conditions of rural and urban households. Moreover, this study will examine the factors influencing labor migration and will assess the impact of labor migration on family's' welfare.

\section{Objectives of the project}

Major Objective: the main objective of the paper to examine the determinants of migration and its impact on socioeconomic welfare of households in Tigrai.

\section{Specific objectives}

The paper will address the following specific objectives

- To analyze the determinants of migration in the region

- To analyze the status and determinants of unemployment in the region

- To assess the effect of migration on socio-economic welfare of households

\section{Research Questions}

For the smooth operation and flow of the paper work, the following questions will be raised that demands a solution

- What factors are motivating the youth to migrate?

- What factors are influencing Unemployment in the region?

- Does migration motivating factors are gender biased?

- What looks like the intensity of migration in the region?

- Does migration affect the socio-economic welfare of households? 


\section{International Journal of Science and Research (IJSR) \\ ISSN (Online): 2319-7064 \\ Index Copernicus Value (2015): 78.96 | Impact Factor (2015): 6.391}

\section{Source of data and Instruments of Data collection}

\section{Sample size}

The study will include 270 households with equal share of these households having migrant members and the nonmigrant households. Based upon the incidence of migration in the zone, 50 percent, of the sample was allocated to three rural areas of Eastern zone and 50 percent was allocated to urban areas who were migrated near the rural areas. Three woredas from the zone, known for their high level of migration, was selected purposefully and sample households will be selected randomly from the frame list of the migrant and non migrant households.

\section{Source of data}

The study depends on both primary and secondary sources of information. The primary data was collected through structured and semi structured questionnaire. In addition, structured and semi structured interview with woreda and tabia officers and focus group discussion was carried out with key stakeholders having deep knowledge about the situation of migration in the specific tabia.

The secondary data mainly focused on published and unpublished reports of the Ministry of Social Affairs of Ethiopia, the Regional government of Tigrai bureau of social affairs and the publication and reports of woreda social affairs was the main inputs.

\section{Instrument of data collection}

Both probability and non-probability sampling techniques was employed in the study. The probability sampling technique depends on simple random sampling, systematic sampling; and the non-probability sampling technique focuses on the quota sampling.

\section{Method of data analysis}

In this part methods and tools of analysis was addressed for each of the objectives that demands model based investigation. Accordingly, the determinants of migration and the socio-economic effects of migration were taken the lead. Descriptive statistics like percentages, mean, standard deviation and other was used to describe some contents of the study which can be treated or represented with appropriate table, graphs and charts. The model based analysis on the determinants of migration and socioeconomic analysis will be carried out using the STATA and DASP packages and was presented in the usual presentation of findings.

\section{Determinants of migration}

To analyze the factors influencing migration, OLS was employed as the decision to migrate proxy by remittance $\mathrm{Yi}=\mathrm{B} 0+\mathrm{B} 1 \mathrm{x} 1+\mathrm{B} 2 \times 2+\mathrm{B} 3 \mathrm{X} 3+\ldots .+\mathrm{Bn} \times n$

\section{Results, Analysis and Discussion}

Description of the variables
Table 1: Sampled households with respect to migration pattern from urban and rural woredas of the zone

\begin{tabular}{|c|c|c|c|}
\hline Woredas & Freq. & Percent & Cum. \\
\hline Adigrat & 45 & 16.67 & 16.67 \\
\hline AsibiWenberta & 45 & 16.67 & 33.33 \\
\hline GantaAfeshum & 45 & 16.67 & 50 \\
\hline GolegoleNale & 45 & 16.67 & 66.67 \\
\hline KeletAwelalo & 45 & 16.67 & 83.33 \\
\hline Wukro & 45 & 16.67 & 100 \\
\hline Total & 270 & 100 & \\
\hline
\end{tabular}

The data were collected from 3 woredas one from urban and one from rural kebele. These kebles are Adigrat town, GantaAfeshum, AtsbiWenberta, GolgolNale, Wukro and kilteAwlaelokebeles with equal representation. Since the researchers can not differentiate migrants from non-migrants equal weight to all woredas were given in this research paper.

Table 4.2

\begin{tabular}{|c|c|r|c|c|r|}
\hline Variable & Obs & \multicolumn{1}{|c|}{ Mean } & Std. Dev. & Min & Max \\
\hline hhage & 270 & 48.2 & 6.556361 & 30 & 60 \\
\hline hhdep & 270 & 0.4777778 & 0.6881003 & 0 & 4 \\
\hline
\end{tabular}

\begin{tabular}{|c|c|c|c|}
\hline hhactive & Freq. & Percent & Cum. \\
\hline 1 & 12 & 4.44 & 4.44 \\
\hline 2 & 18 & 6.67 & 11.11 \\
\hline 3 & 60 & 22.22 & 33.33 \\
\hline 4 & 135 & 50 & 83.33 \\
\hline 5 & 30 & 11.11 & 94.44 \\
\hline 6 & 15 & 5.56 & 100 \\
\hline Total & 270 & 100 & \\
\hline
\end{tabular}

\begin{tabular}{|c|c|c|c|}
\hline hhhstat & Freq. & Percent & Cum. \\
\hline 0 & 126 & 46.67 & 46.67 \\
\hline 1 & 144 & 53.33 & 100 \\
\hline Total & 270 & 100 & \\
\hline
\end{tabular}

\begin{tabular}{|c|c|c|c|}
\hline hhhstat & Freq. & Percent & Cum. \\
\hline 0 & 42 & 15.56 & 15.56 \\
\hline 1 & 228 & 84.44 & 100 \\
\hline Total & 270 & 100 & \\
\hline \multicolumn{4}{|l|}{ 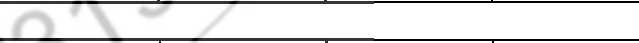 } \\
\hline Illiterate & 69 & 25.56 & 25.56 \\
\hline Informal & 129 & 47.78 & 73.33 \\
\hline Primary & 36 & 13.33 & 86.67 \\
\hline Secondary & 36 & 13.33 & 100 \\
\hline Total & 270 & 100 & \\
\hline
\end{tabular}

The average age of the household was 48.2 with minimum 30 and maximum 60 years. From the collected data, 69 household heads were illiterate, 129 household heads were trained informally, 36 household heads were learnt primary education and the remaining 36 household heads were trained secondary. The average age of the household head is 48.2 with standard deviation 6.556361 . The number of dependents in the household is 0.4777778 . From the total respondents 42 households were female headed while 228 were male headed. 


\section{International Journal of Science and Research (IJSR)}

ISSN (Online): 2319-7064

Index Copernicus Value (2015): 78.96 | Impact Factor (2015): 6.391

Determinants of Migration

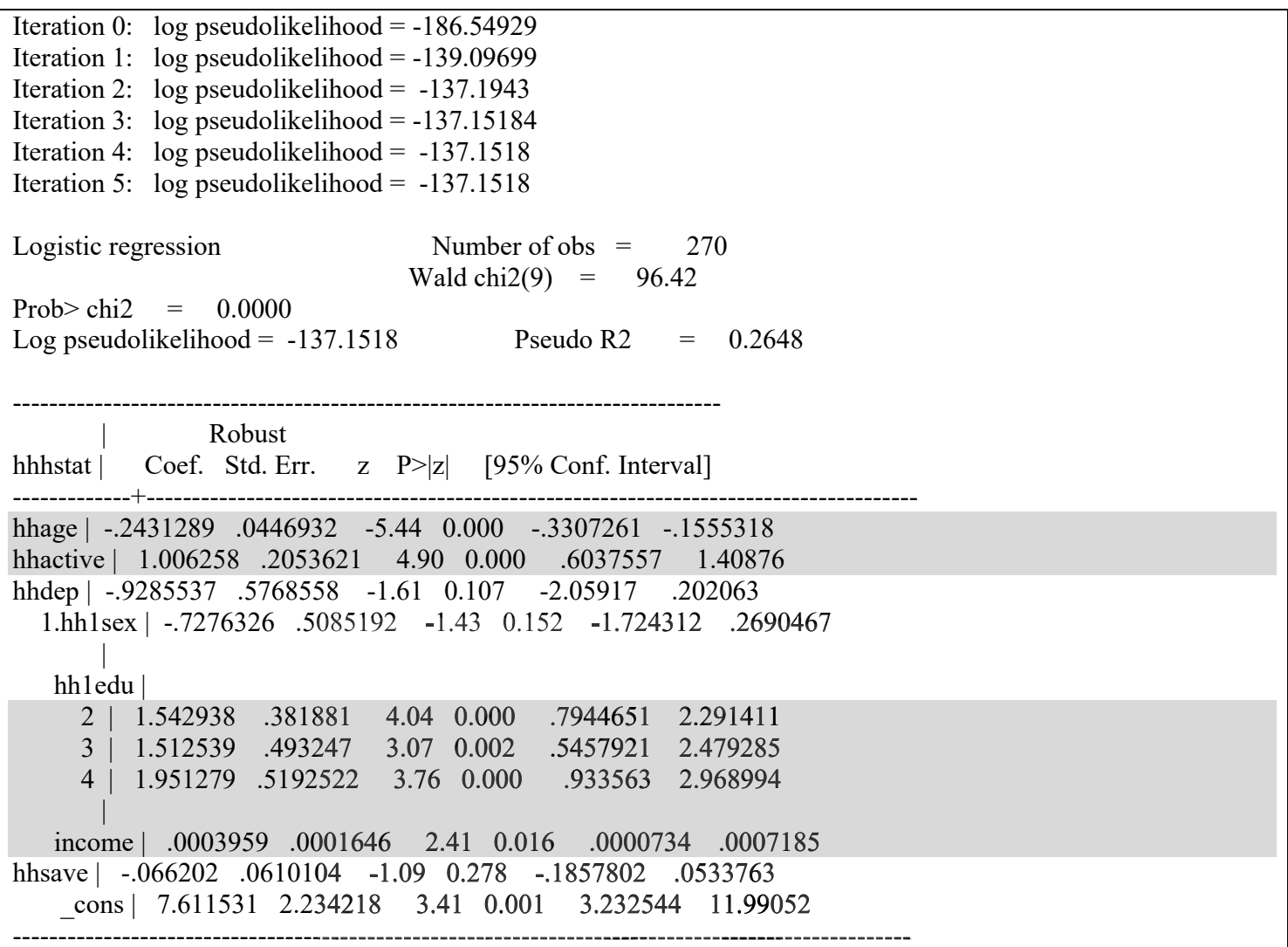

\section{Effects of Migration}

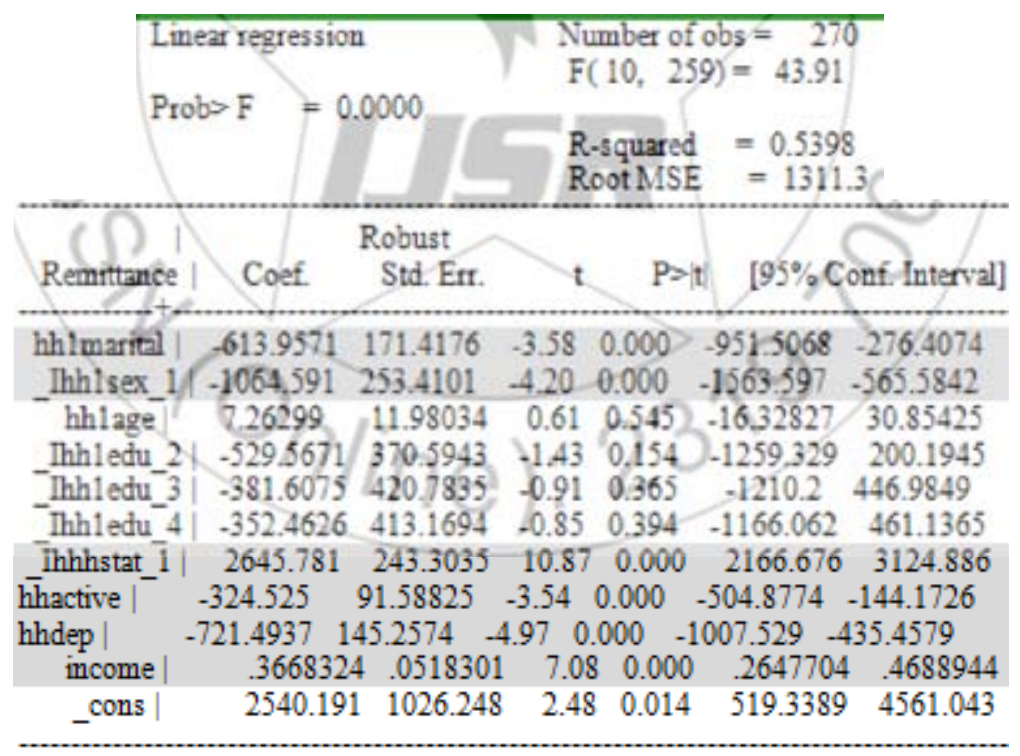

In the estimated regression, remittance was taken as a dependent variable. According to the estimation results in the above table, the average result shows being female has lower remittance to their family than being male by 1064.6 birr. In addition, migrants have higher remittance than nonmigrants by 2645.8 birr. According to the average result, an increase in the number of an out-migrant of a household member leads to an increase in net remittance income by about 2074 ETB per annum. Moreover, households with increasing number of dependents have lower income remittance by about 721.5 birr, on average. Likewise, married people have lower remittance than unmarried people by 613.9 birr. This perhaps would be because married people start up their own life in destination and incur more expenses and investment in destination that eventually may affect the amount of remittance to be sent home. Unmarried migrants live in destination region for a short period of time and return back to their permanent origin with their savings. In addition, the F-test for all cases of observation produced significant results showing that the observed r-square is statistically reliable. Remittances not only facilitate farm investment but also enhance total household income and directly contribute for household consumption.

\section{Volume 6 Issue 1, January 2017 www.ijsr.net}




\section{International Journal of Science and Research (IJSR) \\ ISSN (Online): 2319-7064}

Index Copernicus Value (2015): 78.96 | Impact Factor (2015): 6.391

\section{Cost of Migration}

\begin{tabular}{|l|l|l|l|l|l|} 
Variable & Obs & Mean & Std. Dev. & Min & Max \\
\hline
\end{tabular}

\begin{tabular}{|l|l|l|l|l|l|} 
Cost of migration & 270 & 633.5 & 753.48 & 0 & 3050 \\
\hline
\end{tabular}

In the conducted survey 633.5 birr was the average per person incurred cost from the migrants. When migrants start to travel to destination for a first time, transportation and initial adjustment costs (in the destination region) are covered by either their families or in some cases by friends and/or relatives living in origin/destination region.

As a result, cost of migration for new migrants with networks would be lower. In general, networks play an important role: in reducing the costs of migration, in increasing the probability of getting a job in destination and then maximizing the positive sides of migration as well as in lessening the opportunity cost of migration with respect to farm income.

\section{Income comparison of households}

\begin{tabular}{|c|c|c|c|}
\hline \multirow{2}{*}{ hhhstat } & \multicolumn{3}{|c|}{ Summary of income } \\
\cline { 2 - 4 } & Mean & Std. Dev. & Freq. \\
\hline Non-Migrant & 1761.9048 & 1640.7855 & 126 \\
\hline Migrant & 1792.7083 & 1193.7332 & 144 \\
\hline Total & 1778.3333 & 1417.313 & 270 \\
\hline
\end{tabular}

From the collected data, 126 non migrants and 144 migrants were collected from six woredas. Form the above table, migrants have a little higher income than the non-migrants.

\begin{tabular}{|l|c|c|r|c|r|}
\hline Variable & Obs & Mean & Std. Dev. & Min & Max \\
\hline income 2003 & 270 & 2940.026 & 2784.011 & 0 & 20500 \\
\hline income 2007 & 270 & 3374.859 & 2488.07 & 0 & 9500 \\
\hline
\end{tabular}

from the table above, the households income were improved after five years in 2007 E.C by 434.8 birr.

\section{Reasons for Migration}

Among the main reasons to migration total crop failure, lack of rainfall, pest outbreak, flooding, landlessness accordingly are the major reason of rural urban migration.

\begin{tabular}{|c|c|c|c|}
\hline \multirow{2}{*}{ hhhstat } & \multicolumn{3}{|c|}{ Summary of howlong } \\
\cline { 2 - 4 } & Mean & Std. Dev. & Freq. \\
\hline 0 & 0 & 0 & 126 \\
\hline 1 & 11.895833 & 7.9603201 & 144 \\
\hline Total & 0.3444444 & 8.3088538 & 270 \\
\hline
\end{tabular}

From the migrants the average years of stay away from their village is 11.895833 years with 7.9603201 years standard deviation

\begin{tabular}{|c|c|c|c|}
\hline \multirow{2}{*}{ Why come } & \multicolumn{3}{|c|}{ Summary of hhhstat } \\
\cline { 2 - 4 } & Mean & Std. Dev. & Freq. \\
\hline 0 & 0.0666667 & 0.2503729 & 125 \\
\hline to build house & 1 & 0 & 36 \\
\hline to teach my Children & 1 & 0 & 6 \\
\hline to live good life & 1 & 0 & 57 \\
\hline to work & 1 & 0 & 36 \\
\hline Total & 0.5333333 & 0.4998141 & 270 \\
\hline
\end{tabular}

The majority who came to urban towns from their village is about 57 respondents replied to live good life while the remaining 72 with equal shares came to build houses and to work in trade activities in urban areas. The remaining 6 respondents replied they came to urban towns to teach their children.

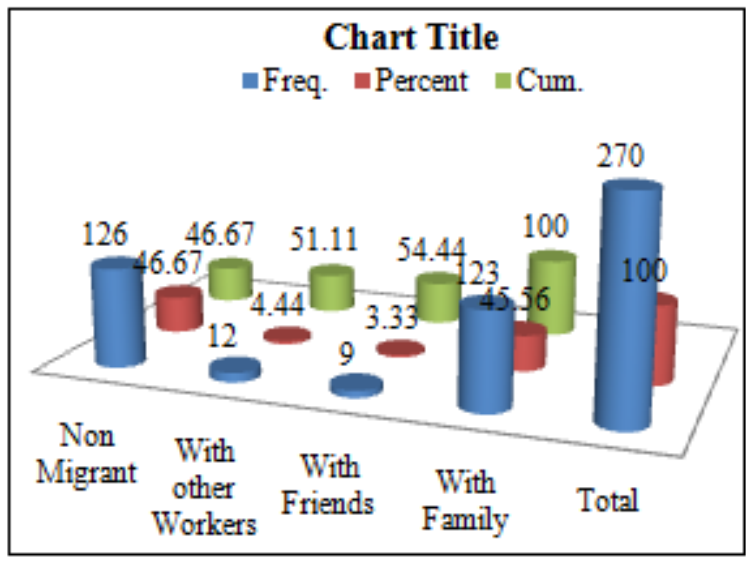

45.56 percent of the migrants stayed with their family while they were migrated. 4.44 percent and 3.33 percent were stayed with other workers and with friends respectively.

How many migrants are there in your household?

\begin{tabular}{|c|c|c|c|}
\hline Migrants & Freq. & Percent & Cum. \\
\hline 0 & 126 & 46.67 & 46.67 \\
\hline 2 & 36 & 13.33 & 60 \\
\hline 3 & 39 & 14.44 & 74.44 \\
\hline 4 & 69 & 25.56 & 100 \\
\hline Total & 270 & 100 & \\
\hline
\end{tabular}

From the ttal 270 respondents, 126 were non-migrants. From the total migrants, 36 respondents replied, two migrants live with household, 39 respondents replied 3 migrants live with the household while 69 respondents replied 4 migrants live with the household.

\section{Conclusion and Recommendation}

\section{Conclusion}

The descriptive analysis of this paper has focused on the main patterns and drivers of migration flows to Adigrat, Wukro and Atsibi Wenberta; the demographic characteristics, economic and social background and living conditions of migrants and some of the possible impacts of migration on family members who stay behind.

On the other hand, in this research work high costs of living and low level of education of migrants had created disincentives and constraints of migration to the towns. In addition, the research suggests that the reason for migrating changes across different area of destination, with Adigrat attracting the greatest flows of work- and educational-related migration which can be regarded as pull factors while in the remaining two towns Wukro and Atsibi Wenberta the greatest flows can be regarded as push factors because of less agricultural productivity, no or less access to land and poverty. From this findings, the researchers conclude that flow of migration in the region have different patterns with some main knowledge gaps and low possible directions and policy recommendations. 


\section{International Journal of Science and Research (IJSR) \\ ISSN (Online): 2319-7064}

Index Copernicus Value (2015): 78.96 | Impact Factor (2015): 6.391

The study also finds migrants afford to send money and other resources to home. Though the remittance rate is low, the reasons might limit the benefits accruing to family members left behind. In addition, migration has indirect effects that might spread from migrants to non-migrant households and to sending-communities. Nevertheless, migration in the rural areas has a negative impact on family members who stay behind by reducing labor supply or by depriving children of parents' presence and care. The research also has a key point on the effect of migration on human capital endowments in areas of origin whether it has adverse effect or not.

Likewise the decision of migration in the study area is not only done by the individual migrants only but also within a household decision-making framework.

\section{Recommendation}

In general, rural-urban migration plays a major role in rural modernization and transformation and meeting labor demands in urban areas. Remittances sent to families of migrants residing in rural origin can contribute for rural development not only by facilitating investment but also by enhancing the living standard of households and reducing chronic poverty. Rural-urban migration can be taken as a strategy particularly for poorest groups of rural households where they can supplement their farm income and then diversify risks.

The following policy recommendations are drawn taking to account the current circumstances of rural-urban migration in the region in general and the case study in particular.

- In most policy papers rural urban migration is considered as undesirable incidence. However, rural urban migration should be incorporated in the GTP II plan to enhance rural development and reduce poverty. The policy papers should be designed in the ways of maximizing the benefits of migration and minimizing the negative outcomes.

- In the process of rural commercialization and transformation the rural development policy should enhance the productivity of labor and improving the living standard of the rural population. Moreover, rural development policies should pave opportunities to enable migrants to involve in farm and non-farm investments. Non-farm enterprises serve as a means of rural livelihood diversification and reduce the pressure on land. Furthermore, rural development policies should pay a special attention for the poorest groups of the rural population who migrate as a result of chronic poverty. The poor should participate from the planning to evaluation of rural development projects in this regard.

- Vocational training should be given for rural migrants to equip them with the necessary skills and make them competitive in the non-farm labor market.

- Rural-urban migration facilitates the linkages between agriculture and industrial development particularly in reallocation of labor from less productive sectors to more productive sectors. Therefore, urban and rural development policies should be consistent and complementary to each other.

- Land is an important asset for the rural population. Land fragmentation as a result of population growth is one of the challenges of rural households forcing households to migrate in the rural areas of the region. The growth of labor force is too high as compared to the growth of available resources and employment opportunities. Thus, population and land use policies should be revised regularly based on existing situations.

- The government and private sector should create employment opportunities in the rural and urban economies to reduce the level of open and disguised unemployment as well as chronic poverty of rural regions. In this regard, the government should create conducive business environment and infrastructure for the private sector.

- Agriculture is the back of the economy of the country. Small-scale farming is unable to feed the increasing population. In addition, the sector is affected by natural calamities and recurrent droughts and forcing rural households to migrate. Therefore, modern technologies, mechanized farming and irrigated agriculture should be introduced in considerable extent.

Rural households get information regarding the opportunities in urban regions from friends or relatives informally. In such cases, information is often biased and exaggerated leading to excess migration to urban centers, increasing the unemployment level, exploitation of labor and human trafficking. Thus, access to information should be improved for potential rural migrants.

\section{References}

[1] Abdulkadir, M.S. (2010) "Economic Crises, Poverty, Unemployment, Slave and Human Trafficking in Nigeria".( Paper presented at the International Colloquium on Slavery, Slave Trade and their Consequences). August 23-26.

[2] Abdulkadir, M.S. (2010) "Changing World Economy, Economic / Adjustment Problems in Nigeria: c.19301999". (Paper presented at the Conference on Immigration in the Southeast: Defining Problems, Finding Solutions Kennesaw State University, Kennesaw, Georgia. USA. October 27-29).

[3] Adepoju, A. (1977). Migration and Development in Tropical Africa: Some Research, Priorities. African Affairs, 76(33): 210-225.

[4] Bariagaber, A. (1997). Political Violence and the Uprooted in the Horn of Africa: A Study of Refugee Flows from Ethiopia. Journal of Black Studies, 28(1), 26-42.

[5] Berhanu, N., Kassahun, T., Seid, N. \&Zekarias, M. (2004). Using Resources from Migration for Development in Ethiopia. Ethiopian Economic Association/ Ethiopian Economic Policy Research Institute.

[6] Berhanu, B. and M.J.White. (2000). War, Famine and Female Migration in Ethiopia, 1960-1989. Economic Development and Cultural Change, 49 (1): 91-113.

[7] Brockerhoff, M and Brenan, E. (1998). The poverty of cities in developing countries. Population and Development Review, 24 (1):75-114.Central Statistical Authority (1992).The analysis of local moves and internal migration, Vol. II. Addis Ababa, Ethiopia: Central Statistical Authority.

\section{Volume 6 Issue 1, January 2017}




\section{International Journal of Science and Research (IJSR) \\ ISSN (Online): 2319-7064 \\ Index Copernicus Value (2015): 78.96 | Impact Factor (2015): 6.391}

[8]

(1998). The 1994 Population and Housing

Census of Ethiopian: Result at Country Level, Vol. 1

Statistical Report, June 1998. Addis Ababa,

Ethiopia:Central Statistical Authority.

[9] . (1999). The 1994 Population and Housing Census of Ethiopian: Result at Country Level, Vol.11 Analytical Report, June 1999. Addis Ababa, Ethiopia: Central Statistical Authority.

[10]Dejene, A. (1990). Environment, Famine, and politics in Ethiopia: A view from the Village. Boulder and London: Lynne Rienner Publishers.

[11]Ezra, M. (2001). Ecological Degradation, Rural Poverty, and Migration in Ethiopia: A Contextual Analysis. Policy Reasearch Division, Population Council WorkingPaper, No. 149.

[12] Gebre, Y.D. (2001). Population Displacement and Food Insecurity in Ethiopia: Resettlement, Settlers and Hosts. University of Florida: PhD Dissertation.

[13] Gurmu, E., Sidney Goldstein and Alice Goldstein, (2000). Migration, Gender and Health Survey in Five Regions of Ethiopia: 1998. (A United Nation Training andResearch Project on the Interrelations of Migration and Economic Change, Women's Status, Reproduction and Health). Addis Ababa: Addis Ababa University and Providence: Brown University.

[14] International Labour Organization (ILO). "Forced labour, child labour and human trafficking in Europe: An ILO Perspective," 2011.

[15]Kiros, G-E. and M.J. White. (2004). Migration, community context and child immunization in Ethiopia. Social Science and Medicine, 59: 2603-2616.

[16]Lockwood, V. S. (1990). Development and Return Migration to Rural Polynesia.

[17] Mariam, M.W. (1985). The social consequences of famine. In Fasil Gebre-Kiro (ed) Changing Rural Poverty. Trenton: Africa World Press.

[18] Narayanmoorthy, A., Jyotishi, A. and Deshmukh, R.S. (1999) Agricultural growth and migration: Search for new evidence. Indian Journal of Agricultural Extension,54(3). NAPTIP News (2010) Vol.2, No.2, August-October.

[19] Organization for Migration (IOM): Mobilization and Utilization of Diaspora Resources for Development in Ethiopia", Addis Ababa, Ethiopia, March 2004.Migration Review, 24(2): 347-371.

[20] Stark, O. and Bloom D.E. (1985). The new economics of labor migration. American Economic Review, 75: 845-867.

[21]UN-HABITAT. (2003). The Challenge of Slums: Global Report on Human Settlements. London and Sterling: Earthscan.

[22] United Nations Protocol, (2000) "Prevention, Suppress, and Punish Trafficking in Persons, Especially Women and Children: Supplementing the UN Convention against Trans- national Organized Crime". United Nations High Commission on Refugess (UNHCR). (2012). Ethiopia. Retrieved 14 November 2012 from www.unhcr.org

[23]2011 Country Report on Human Rights Practices, released by the Bureau of Democracy, Human Rights and Labor, U.S Department of State, 25 Feb. 2012. 